\title{
Assessment of ocular surface toxicity after topical instillation of nitric oxide donors
}

\author{
Avaliação da toxicidade na superfície ocular após instilação tópica de doadores de óxido nítrico
}

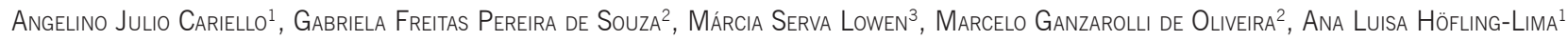

\begin{abstract}
Purpose: To evaluate the ocular surface toxicity of two nitric oxide donors in ex vivo and in vivo animal models: S-nitrosoglutathione (GSNO) and S-nitroso-Nacetylcysteine (SNAC) in a hydroxypropyl methylcellulose (HPMC) matrix at final concentrations 1.0 and $10.0 \mathrm{mM}$.

Methods: Ex vivo GSNO and SNAC toxicities were clinically and histologically analyzed using freshly excised pig eyeballs. In vivo experiments were performed with 20 albino rabbits which were randomized into 4 groups (5 animals each): Groups 1 and 2 received instillations of $150 \mu \mathrm{L}$ of aqueous HPMC solution containing GSNO 1.0 and $10.0 \mathrm{mM}$, respectively, in one of the eyes; Groups 3 and 4 received instillations of $150 \mu \mathrm{L}$ of aqueous HPMC solution-containing SNAC 1.0 and $10.0 \mathrm{mM}$, respectively, in one of the eyes. The contralateral eyes in each group received aqueous HPMC as a control. All animals underwent clinical evaluation on a slit lamp and the eyes were scored according to a modified Draize eye test and were histologically analyzed.

Results: Pig eyeballs showed no signs of perforation, erosion, corneal opacity or other gross damage. These findings were confirmed by histological analysis. There was no difference between control and treated rabbit eyes according to the Draize eye test score in all groups ( $p>0.05)$. All formulations showed a mean score under 1 and were classified as "non-irritating". There was no evidence of tissue toxicity in the histological analysis in all animals.

Conclusion: Aqueous HPMC solutions containing GSNO and SNAC at concentrations up to $10.0 \mathrm{mM}$ do not induce ocular irritation.
\end{abstract}

Keywords: Drug toxicity; S-nitrosothiols; S-nitrosoglutathione; Methylcellulose; Nitric oxide donors

\section{RESUMO}

Objetivo: Avaliar a toxidade na superfície ocular de dois compostos doadores de óxido nítrico em modelos ex vivo e in vivo: S-nitrosoglutationa (GSNO) e S-nitroso$\mathrm{N}$-acetilcisteína (SNAC), em uma matriz de hidroxipropil metilcelulose (HPMC) nas concentrações finais de 1,0 and 10,0 mM.

Métodos: As toxicidades de GSNO e SNAC foram avaliadas clinicamente e histologicamente em modelo ex vivo usando globos oculares porcinos recém excisados. Experimentos in vivo foram realizados com 20 coelhos albinos que foram randomizados em 4 grupos (5 animais em cada): Os grupos 1 e 2 receberam instilações de $150 \mu \mathrm{L}$ de solução aquosa de HPMC contendo GSNO 1,0 e 10,0 mM, respectivamente, em um dos olhos; Os grupos 3 e 4 receberam instilações de $150 \mu \mathrm{L}$ de solução aquosa de HPMC contendo SNAC 1,0 and 10,0 mM, respectivamente, em um dos olhos. Os olhos contralaterias em cada grupo receberam solução aquosa de HPMC como controle. Todos os animais foram clinicamente avaliados em lâmpada de fenda e os olhos foram pontuados de acordo com o teste de Draize modificado e analisados histologicamente.

Resultados: Os globos oculares porcinos não apresentaram sinais de perfuração, erosão, opacidade da córnea ou outros danos graves. Esses resultados foram confirmados pela análise histológica. Não houve diferença entre os olhos dos coelhos tratados e controles de acordo com a pontuação do teste de Draize em todos os grupos ( $p>0,05)$. Todas as formulações apresentaram um escore médio menor do que 1 e foram classificadas como "não-irritantes". Não houve evidência de toxicidade tecidual nas análises histológicas em todos os animais.

Conclusão: Soluções aquosas de HPMC contendo GSNO e SNAC em concentrações até 10,0 mM não induzem irritação ocular.

Descritores: Toxicidade de drogas; S-nitrosotióis; S-nitrosoglutationa, Metilcelulose; Doadores de óxido nítrico

\section{INTRODUCTION}

Nitric Oxide (NO) is a signaling molecule responsible for several physiological and pathophysiological actions throughout the human body, including blood flow control and modulation of immune response ${ }^{(1,2)}$. In mammals, $\mathrm{NO}$ is considered to circulate as S-nitrosothiols, mainly S-nitrosoglutathione (GSNO), S-nitrosoalbumin and possibly S-nitrosohemoglobin ${ }^{(3,4)}$. Synthetic GSNO and S-nitroso-Nacetylcysteine (SNAC) were already used as exogenous NO donors in different experimental settings $s^{(5,6)}$.

In the eye, NO has been shown to be a key regulator of vascular tone in ophthalmic arteries ${ }^{(7,8)}$ and animal and human studies have demonstrated reduction in the choroidal blood flow with systemic infusion of NO inhibitors ${ }^{(9-11)}$. NO donors were also shown to increase blood flow in the retina, choroid and the optic nerve head ${ }^{(12,13)}$. Additionally, some studies have addressed the beneficial effect of
S-nitrosothiols on the reduction of intraocular pressure(14-17), and suggest that S-nitrosothiols are potential new drugs for the treatment of glaucoma and other ocular ischemic diseases ${ }^{(13)}$.

Nitric oxide-mediated antimicrobial activity has also been the focus of recent research ${ }^{(18,19)}$. GSNO and SNAC displayed bactericidal and bacteriostatic activities against several Gram-positive and Gram-negative clinical isolates from patients with bacterial infectious keratitis ${ }^{(20)}$. In addition, GSNO and SNAC were also shown to exert potent antimicrobial actions against trophozoites of Acanthamoeba castellanii, the etiological agent responsible for a devastating sight-threatening keratitis $^{(21)}$. These data suggest that $\mathrm{NO}$ donors are important candidates for treating infectious eye diseases. Other possible therapeutic applications of S-nitrosothiols in ophthalmology include corneal wound healing(22), antifibrotic effect in glaucoma filtering surgery ${ }^{(23)}$ and anti-inflammatory action in autoimmune uveitis ${ }^{(24)}$.
Submitted for publication: August 16, 2012

Accepted for publication: November 20, 2012

Study carried out at Universidade Federal de São Paulo, São Paulo, SP, Brazil.

Physician, Department of Ophthalmology, Universidade Federal de São Paulo, São Paulo, SP, Brazil.

${ }^{2}$ Chemistry, Institute of Chemistry, Universidade Estadual de Campinas, Campinas, SP, Brazil.

${ }^{3}$ Physician, Department of Pathology, Universidade Federal de São Paulo, São Paulo, SP, Brazil.
Funding: This study was supported by GFPS received a studentship from FAPESP, (grant \#07/55877-3). MGO acknowledges support from CNPq (grant \#309390/2011-7) and FAPESP (grant \#2011/18334-7).

Disclosure of potential conflicts of interest: A.J.Cariello, None; G.F.P.de Souza, received a studentship from FAPESP, Proj.07/55877-3; M.S.Lowen, None; M.G.de Oliveira, None; A.L.Höfling-Lima, None Correspondence address: Angelino Julio Cariello. Sadalla Amin Ghanem Eye Hospital. Rua Abdon Batista, 146 - Joinville (SC) - 89201-010 - Brazil - E-mail: angelino@sadalla.com.br Ethic committee from UNIFESP: number 1573/08. 
Despite these potential clinical applications of S-nitrosothiols in ophthalmology, the ocular toxicity of these compounds is not yet known. The purpose of the present study was to evaluate the ocular surface toxicity of GSNO and SNAC after topical installations in ex vivo and in vivo animal models.

\section{METHODS}

\section{Materials}

Glutathione (g-Glu-Cys-Glu, GSH), N-acetyl-cysteine (NAC), sodium nitrite (NaNO2), hydrochloric acid $(\mathrm{HCl})$, phosphate buffer saline solution, pH 7.4 (PBS) and acetone were purchased from Sigma (St. Louis, MO, USA) and used as received. Ketamine and xylazine hydrochlorides were purchased from Phoenix Scientific Inc. (St. Joseph, MO, USA). Hydroxypropyl methylcellulose (HPMC) was manufactured by Dow Chemical Company (Midland, MI, USA).

\section{SyNTHESIS OF GSNO AND SNAC}

GSNO and SNAC were synthesized as previously described ${ }^{(25)}$. SNAC solutions were prepared from a freshly made stock solution $40.0 \mathrm{mM}$ and further diluted in PBS to 2.0 and $20.0 \mathrm{mM}$ with a final $\mathrm{pH}$ 7.0. GSNO solutions 2.0 and $20.0 \mathrm{mM}$, pH 7.0, were prepared immediately before use from solid GSNO.

\section{Preparation of S-nitrosothiols-containing HPMC formulations}

SNAC and GSNO concentrations 1.0 and 10.0 mM in HPMC solution $2 \%(\mathrm{w} / \mathrm{v})$ were prepared by mixing equal volumes of aqueous HPMC solution 4\% (w/v) and SNAC or GSNO solutions 2.0 or $20.0 \mathrm{mM}$, prepared as above, under stirring. These formulations were designated as SNAC 1, SNAC 10, GSNO 1 and GSNO 10, respectively.

\section{Stability of the HPMC-containing S-Nitrosothiols formulations}

The concentrations of SNAC and GSNO in the HPMC formulations were spectrophotometrically monitored during their storage in the dark at $37^{\circ} \mathrm{C}$ for $1 \mathrm{~h}$, based on their characteristic optical absorption bands at $336 \mathrm{~nm}$, assigned to the -SNO moiety. A Diode-array spectrophotometer (HP-8453, Hewlett-Packard, Palo Alto, CA, USA) was used for this purpose. GSNO and SNAC solutions $10 \mathrm{mmol} \mathrm{L}^{-1}$ were monitored over $1 \mathrm{~h}$ in a $1 \mathrm{~cm}$ optical path quartz cuvette. Concentration changes in the solutions were calculated based on the molar absorption coefficient of GSNO and SNAC (900.0 mol-1 $\mathrm{L} \mathrm{cm}^{-1}$ at $\left.336 \mathrm{~nm}\right)$.

\section{Animals}

Male New Zealand healthy albino rabbits (1.8 to $2.2 \mathrm{~kg}$ ) were purchased from the Center of Development of Experimental Models for Medicine and Biology (CEDEME, São Paulo, Brazil). All animals were handled in accordance with the NIH Principles of laboratory animal care and the ARVO statement for the use of animals in ophthalmic and vision research. The experimental protocol was previously approved by the Research Ethics Committee from Federal University of São Paulo. All animals were acclimated and housed in individual cages (designed to avoid accidental injury) and kept in a room with 12-h light-dark diurnal cycle, adequate air turnover and constant temperature $\left(22^{\circ} \mathrm{C}\right)$, receiving standard rabbit chow (Purina, São Paulo, Brazil) and water ad libitum. All procedures were performed under systemic anesthesia with intramuscular injection of $30 \mathrm{mg} / \mathrm{kg}$ of ketamine hydrochloride and $5 \mathrm{mg} / \mathrm{kg}$ of xylazine hydrochloride.

\section{Ex VIVO EVALUATION}

For ethical reasons, the toxicities of the S-nitrosothiols formulations were previously evaluated in an ex vivo model to lessen the likelihood of any non-selective effects in rabbit eyes during the in vivo tests. Twenty-five freshly excised pig eyeballs were obtained from a local slaughterhouse immediately after slaughter, washed thoroughly with PBS and divided into five groups. The eyeballs of each of four experimental groups were instilled with $500 \mu \mathrm{L}$ of SNAC 1, SNAC 10, GSNO 1 or GSNO 10 formulations onto the cornea and conjunctiva.

The fifth group received the same volume of pure HPMC solution $2 \%(\mathrm{w} / \mathrm{v})$ and served as a control. The eyeballs were clinically analyzed under a surgical microscope before instillation and $30 \mathrm{~min}$ and $1 \mathrm{~h}$ after instillation. The eyeballs were fixed in $10 \%$ formalin solution for 48 h, stained with hematoxylin-eosin and subjected to histological analysis.

\section{OCular tolerability}

Twenty rabbits were randomized into 4 groups with 5 animals each: groups 1 and 2 received instillations of $150 \mathrm{~mL}$ of GSNO 1 and GSNO 10, respectively, in one eye (randomly chosen by coin toss between right or left side); groups 3 and 4 received $150 \mathrm{~mL}$ of SNAC 1 and SNAC 10, respectively, in one eye (randomly chosen as above). The contralateral eye of each animal received aqueous HPMC as a control. A sentinel study with a single animal per group was performed before the entire experiment and showed no clinical and histological damage up to $72 \mathrm{~h}$. Based on this result, the evaluation of toxicity was limited to $24 \mathrm{~h}$.

A modified Draize test was used to access potential ocular irritancy ${ }^{(26)}$. Slit lamp examination was performed before drug exposure to ensure normal ocular surface integrity and repeated 1 and $24 \mathrm{~h}$ after drug instillation. The score system evaluated the corneal opacity (scored from 0 to 4), iritis (from 0 to 2 ) and conjunctival redness (from 0 to 3$)^{(26)}$. The final score was calculated by summing the cornea, iris and conjunctiva scores, which ranged from 0 to 9 . The score criteria were defined according to the following cutoffs: under 1: non-irritating; 1 to 4: mildly irritating; 5 to 7: moderately irritating; over 7: severely irritating.

After $24 \mathrm{~h}$ all animals were sacrificed with intravenous pentobarbital sodium injection under anesthesia, the eyes were enucleated, fixed in 10\% formalin solution for $48 \mathrm{~h}$ and then histologically analyzed (hematoxylin-eosin stain). All the slit lamp evaluations were performed under double blind conditions (i.e. both the investigator who performed the instillations and the investigator who performed the histological analysis did not know the formulation identity).

\section{Statistical analyses}

Data were expressed as mean \pm standard deviation. The comparisons between Draize score of control and treated eyes were done using the non-parametric Mann-Whitney $U$ test. $P$ values $<0.05$ indicated statistical significance.

\section{RESULTS}

In the ex vivo experiment, all pig eyes showed no signs of perforation, tissue erosion, corneal opacity or other gross damage. The conjunctival and corneal epithelium were preserved and there was no significant difference between treated and control groups. Histological evaluation confirmed the absence of damage in the pig conjunctival and corneal epithelium and the preservation of external and intraocular tissue structures in the treated groups.

In the in vivo experiments, all formulations showed a mean score under 1 and were classified as "non-irritating" compounds. None of the animals developed corneal opacity or iritis. There was no significant difference in the mean score between control and the treated groups 1 and $24 \mathrm{~h}$ after drug instillation ( $p>0.05$ ) (Table 1). The animal blink rate or eye wiping 5 min into the recovery period after anesthesia were unaffected by drug treatment.

The palpebral, cul-de-sac and bulbar conjunctival histologies of all control and treated animals were unchanged. No vessel proliferation or immune cell infiltration was detected. The Goblet-cells were present throughout the entire conjunctival surface with no 
Table 1. Draize eye test score

\begin{tabular}{lcccc}
\hline Compounds & $\begin{array}{c}\text { Interval of } \\
\text { exposure }\end{array}$ & $\begin{array}{c}\text { Treatment } \\
\text { mean } \pm \text { SD }\end{array}$ & $\begin{array}{c}\text { Control } \\
\text { mean } \pm \text { SD }\end{array}$ & p value* \\
\hline SNAC 1 & After 1 hour & $0.2 \pm 0.45$ & $0.2 \pm 0.45$ & 1.00 \\
& After 24 hour & 0 & 0 & - \\
SNAC10 & After 1 hour & $0.4 \pm 0.55$ & $0.2 \pm 0.45$ & 0.69 \\
& After 24 hour & $0.2 \pm 0.45$ & $0.2 \pm 0.45$ & 1.00 \\
GSNO1 & After 1 hour & 0 & 0 & - \\
& After 24 hour & 0 & 0 & - \\
GSNO10 & After 1 hour & $0.4 \pm 0.55$ & $0.2 \pm 0.45$ & 0.69 \\
& After 24 hour & $0.2 \pm 0.45$ & $0.2 \pm 0.45$ & 1.00 \\
\hline
\end{tabular}

SNAC=S-nitroso-N-acetylcysteine; GSNO=S-nitrosoglutathione; SD= standard deviation. * = Mann-Whitney U test.

cytoarchitectural modifications. The limbus was preserved and no inflammatory cell infiltration was noted. The cornea also had an unchanged appearance in all its layers with no angiogenesis or inflammatory signs (Figure 1). No histological modifications were noted in the sclera, iris, lens, choroid and retina.

Evaluation of the stability of the SNAC 10 and GSNO 10 formulations at $37^{\circ} \mathrm{C}$ showed that less than $2 \%$ of the SNAC or GSNO decompose under this condition after $1 \mathrm{~h}$.

\section{DISCUSSION}

In spite of their potential therapeutic applications, the ocular toxicity of GSNO and SNAC had not been characterized yet. Previous studies performed to evaluate the ocular hypotensive effect of other topical NO donors, like sodium nitroprusside and S-nitroso-N-acetylDL-penicillamine reported no adverse effects in the concentration range 1-2 $\mathrm{mM}^{(14,15)}$. Equimolar concentrations of different $\mathrm{NO}$ donors lead to variable levels of detectable $\mathrm{NO}$ metabolites in vitro and in vivo and differences in pharmacological and pharmacokinetic properties of these compounds can lead to different clinical effects in ocular tissues ${ }^{(15)}$. Thus, results obtained with a specific nitric oxide donor cannot always be extended to S-nitrosothiols such as GSNO and SNAC. This was the first standardized study to evaluate the potential toxic effects of topical instillation of aqueous HPMC formulations containing GSNO and SNAC on the surface of the eye. We chose the concentration $1 \mathrm{mM}$, which was previously shown to have in vitro microbicidal effects against trophozoites of Acanthamoeba castellanii(21) and a concentration ten times higher than this in order to explore the toxicity level of these RSNOs.

The Draize rabbit eye test used in the present study has been globally accepted since 1944 as the standard regulatory method for determining the ocular irritation potential of chemical products ${ }^{(27-30)}$. However, its use has been criticized on the bases of ethical considerations since it is employed on live animals. Alternative methods have been discussed for ocular toxicity assessment ${ }^{(30)}$. Many tests have been published using ex vivo tissue and cell culture of animal and human tissue ${ }^{(27,30,31)}$. Despite good reproducibility and sensitivity of several in vitro alternative model assays for ocular irritation, their predictive power was not as reliable as the rabbit Draize eye test ${ }^{(30)}$. Moreover, the majority of these tests do not address the issue of ocular irritation reversibility ${ }^{(32)}$. Ex vivo assays are accepted by regulatory authorities for specific and limited purposes ${ }^{(30)}$. As recommended by regulatory agencies ${ }^{(27,30)}$, in the present study a tiered testing strategy was performed to minimize consequential animal distress. It included concerns about the use of neutral formulations and the use of similar NO donors in animal eyes and ocular tissue described in the literature ${ }^{(14,15)}$.

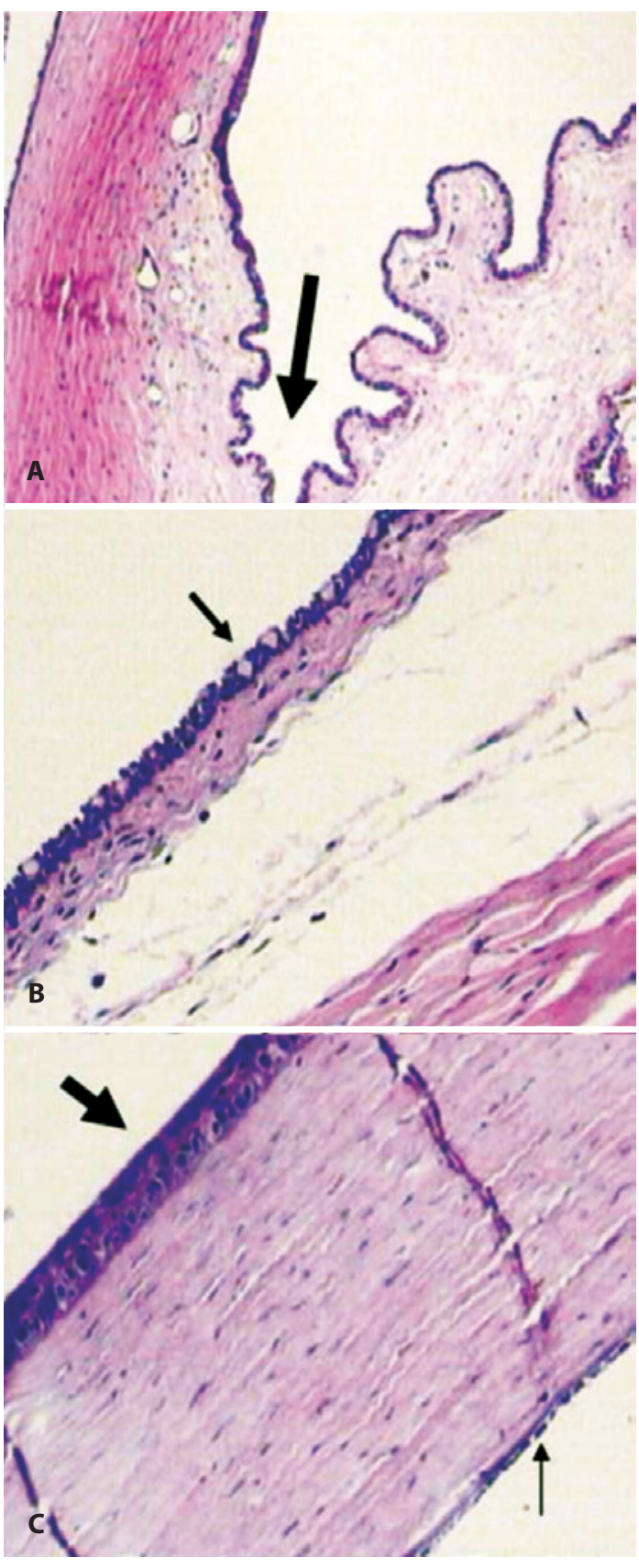

Figure 1. Representative histological images of rabbit eyes after instillation of HPMC formulations containing $10.0 \mathrm{mMS}$-nitrosogluthatione (GSNO) or S-nitroso- $\mathrm{N}$-acetilcysteine (SNAC). (A) Conjunctival cul-de-sac (arrow) (100x). (B) Conjunctival bulbar epithelium (arrow shows a globetcell) (200x). (C) Cornea with normal aspect of epithelium (thick arrow) and endothelium (thin arrow) (200x). Hematoxylin-eosin stain in all pictures.

Considering that the cornea is an avascular tissue, topical administration is a first choice approach for treating diseases of the anterior segment of the eye such as glaucoma and keratitis ${ }^{(33)}$. In addition, topical application may allow the use of locally high concentrations of active principles, with minor or non-significant side effects ${ }^{(33)}$. The HPMC used for the topical instillations of aqueous SNAC and GSNO solutions in this work is a non-toxic hydrophilic mucoadhesive polymer with film forming properties, commonly used in intraocular surgery, topical administrations, artificial tears and drug vehicle ${ }^{(34,35)}$. It is known that tear drainage and blinking action may result in low 
drug absorption following topical ocular application. This consideration accounts for why HPMC solution was used as a vehicle. It acts as a viscosity enhancer and is expected to increase both the residence time of the S-nitrosothiols in the cul-de-sac and their bioavailability on the pre corneal tear film ${ }^{(36-38)}$. Moreover, the low amount of S-nitrosothiols decomposition in the HPMC matrix indicates that this vehicle is appropriate for ocular drug delivery.

Generally, topical drug instillation does not result in the diffusion of the drugs into the vitreous chamber and their pharmacological actions are limited to the anterior ocular surfaces not affecting the retina and the choroid. In fact, Behar-Cohen et al. ${ }^{(14)}$ showed that nitrite levels were undetectable in the rabbit vitreous humor after an NO donor injection into the anterior chamber. The absence of histological alterations and of inflammatory infiltrates observed in our in vivo results is, therefore, consistent with the ex vivo results.

\section{CONCLUSIONS}

Aqueous HPMC formulations containing SNAC or GSNO up to $10 \mathrm{mM}$ display low ocular surface toxicity in topical applications and might be a promising option for treating ocular diseases where nitric oxide may have microbicidal or other beneficial pharmaceutical actions.

\section{ACKNOWLEDGEMENTS}

GFPS received a fellowship from Fundação de Amparo à Pesquisa do Estado de São Paulo, FAPESP (grant \# 07/55877). MGO received a financial support from Conselho Nacional de desenvolvimento científico e tecnológico, CNPq (grant \# 309390/2011-7) and FAPESP, (grant \# 2011/18334-7).

\section{REFERENCES}

1. Wanstall JC, Jeffery TK, Gambino A, Lovren F, Triggle CR. Vascular smooth muscle relaxation mediated by nitric oxide donors: a comparison with acetylcholine, nitric oxide and nitroxyl ion. Br J Pharmacol. 2001;134(3):463-72.

2. Bogdan C. Nitric oxide and the immune response. Nat Immunol. 2001;2(10):907-16. Review.

3. Gladwin MT, Shelhamer JH, Schechter AN, Pease-Fye ME, Waclawiw MA, Panza JA, et al. Role of circulating nitrite and S-nitrosohemoglobin in the regulation of regional blood flow in humans. Proc Natl Acad Sci U S A. 2000;97(21):11482-7.

4. MacArthur PH, Shiva S, Gladwin MT. Measurement of circulating nitrite and S-nitrosothiols by reductive chemiluminescence. J Chromatogr B Analyt Technol Biomed Life Sci. 2007;851(1-2):93-105.

5. Ricardo KF, Shishido SM, de Oliveira MG, Krieger MH. Characterization of the hypotensive effect of S-nitroso- $\mathrm{N}$-acetylcysteine in normotensive and hypertensive conscious rats. Nitric Oxide. 2002;7(1):57-66.

6. Seabra AB, Pankotai E, Fehér M, Somlai A, Kiss L, Bíró L, et al. S-nitrosoglutathionecontaining hydrogel increases dermal blood flow in streptozotocin-induced diabetic rats. Br J Dermatol. 2007;156(5):814-8.

7. Yao K, Tschudi M, Flammer J, Lüscher TF. Endothelium-dependent regulation of vascular tone of the porcine ophthalmic artery. Invest Ophthalmol Vis Sci. 1991; 32(6):1791-8.

8. Lockhart CJ, Gamble AJ, Rea D, Hughes S, McGivern RC, Wolsley C, et al. Nitric oxide modulation of ophthalmic artery blood flow velocity waveform morphology in healthy volunteers. Clin Sci (Lond). 2006;111(1):47-52.

9. Luksch A, Polak K, Beier C, Polska E, Wolzt M, Dorner GT, et al. Effects of systemic NO synthase inhibition on choroidal and optic nerve head blood flow in healthy subjects. Invest Ophthalmol Vis Sci. 2000;41(10):3080-4.

10. Dorner GT, Garhofer G, Kiss B, Polska E, Polak K, Riva CE, et al. Nitric oxide regulates retinal vascular tone in humans. Am J Physiol Heart Circ Physiol. 2003:285(2):H631-6.

11. Simader C, Lung S, Weigert G, Kolodjaschna J, Fuchsjäger-Mayrl G, Schmetterer L, et al. Role of $\mathrm{NO}$ in the control of choroidal blood flow during a decrease in ocular perfusion pressure. Invest Ophthalmol Vis Sci. 2009;50(1):372-7.
12. Grunwald JE, lannaccone A, DuPont J. Effect of isosorbide mononitrate on the human optic nerve and choroidal circulations. Br J Ophthalmol. 1999;83(2):162-7.

13. Schmetterer L, Polak K. Role of nitric oxide in the control of ocular blood flow. Prog Retin Eye Res. 2001;20(6):823-47

14. Behar-Cohen FF, Goureau O, D'Hermies F, Courtois Y. Decreased intraocular pressure induced by nitric oxide donors is correlated to nitrite production in the rabbit eye. Invest Ophthalmol Vis Sci. 1996;37(8):1711-5.

15. Carreiro S, Anderson S, Gukasyan HJ, Krauss A, Prasanna G. Correlation of in vitro and in vivo kinetics of nitric oxide donors in ocular tissues. J Ocul Pharmacol Ther. 2009; 25(2):105-12

16. Chuman H, Chuman T, Nao-i N, Sawada A. The effect of L-arginine on intraocular pressure in the human eye. Curr Eye Res. 2000:20(6):511-6.

17. Kotikoski H, Alajuuma P, Moilanen E, Salmenperä P, Oksala O, Laippala P, et al. Comparison of nitric oxide donors in lowering intraocular pressure in rabbits: role of cyclic GMP. J Ocul Pharmacol Ther. 2002;18(1):11-23. Erratum in J Ocul Pharmacol Ther. 2002;18(4):389.

18. Kaplan SS, Lancaster JR Jr, Basford RE, Simmons RL. Effect of nitric oxide on staphylococcal killing and interactive effect with superoxide. Infect Immun. 1996;64(1):69-76.

19. Stroeher UH, Kidd SP, Stafford SL, Jennings MP, Paton JC, MCEwan AG. A pneumococcal MerR-like regulator and S-nitrosoglutathione reductase are required for systemic virulence. J Infect Dis. 2007;196(12):1820-6.

20. Cariello AJ, Bispo PJ, de Souza GF, Pignatari AC, de Oliveira MG, Hofling-Lima AL. Bactericidal effect of S-nitrosothiols against clinical isolates from keratitis. Clin Ophthalmol. 2012;6:1907-14.

21. Cariello AJ, de Souza GF, Foronda AS, Yu MC, Höfling-Lima AL, de Oliveira MG. In vitro amoebicidal activity of S-nitrosoglutathione and S-nitroso-N-acetylcysteine against trophozoites of Acanthamoeba castellanii. J Antimicrob Chemother. 2010;65(3):588-91.

22. Bonfiglio V, Camillieri G, Avitabile T, Leggio GM, Drago F. Effects of the $\mathrm{COOH}$-terminal tripeptide alpha-MSH(11-13) on corneal epithelial wound healing: role of nitric oxide. Exp Eye Res. 2006;83(6):1366-72.

23. Tannous M, Hutnik CM, Tingey DP, Mutus B. S-nitrosoglutathione photolysis as a novel therapy for antifibrosis in filtration surgery. Invest Ophthalmol Vis Sci. 2000;41(3): 749-55.

24. Haq E, Rohrer B, Nath N, Crosson CE, Singh I. S-nitrosoglutathione prevents interphotoreceptor retinoid-binding protein (IRBP(161-180))-induced experimental autoimmune uveitis. J Ocul Pharmacol Ther. 2007:23(3):221-31.

25. de Souza GF, Yokoyama-Yasunaka JK, Seabra AB, Miguel DC, de Oliveira MG, Uliana SR. Leishmanicidal activity of primary S-nitrosothiols against Leishmania major and Leishmania amazonensis: implications for the treatment of cutaneous leishmaniasis. Nitric Oxide. 2006;15(3):209-16.

26. Chambers WA, Green S, Gupta KC, Hill RN, Huntley K, Hurley PM, et al. Scoring for eye irritation tests. Food Chem Toxicol. 1993;31(2):111-5.

27. Wilhelmus KR. The Draize eye test. Surv Ophthalmol. 2001:45(6):493-515.

28. Liang H, Baudouin C, Faure MO, Lambert G, Brignole-Baudouin F. Comparison of the ocular tolerability of a latanoprost cationic emulsion versus conventional formulations of prostaglandins: an in vivo toxicity assay. Mol Vis. 2009;15:1690-9.

29. Liang H, Baudouin C, Pauly A, Brignole-Baudouin F. Conjunctival and corneal reactions in rabbits following short- and repeated exposure to preservative-free tafluprost, commercially available latanoprost and $0.02 \%$ benzalkonium chloride. $\mathrm{Br}$ J Ophthalmol. 2008;92(9):1275-82.

30. McNamee P, Hibatallah J, Costabel-Farkas M, Goebel C, Araki D, Dufour E, et al. A tiered approach to the use of alternatives to animal testing for the safety assessment of cosmetics: eye irritation. Regul Toxicol Pharmacol. 2009;54(2):197-209.

31. Vinardell MP, Mitjans M. Alternative methods for eye and skin irritation tests: an overview. J Pharm Sci. 2008;97(1):46-59

32. Piehl M, Gilotti A, Donovan A, DeGeorge G, Cerven D. Novel cultured porcine corneal irritancy assay with reversibility endpoint. Toxicol In Vitro. 2010;24(1):231-9.

33. Burstein NL, Anderson JA. Corneal penetration and ocular bioavailability of drugs. J Ocul Pharmacol. 1985;1(3):309-26.

34. Waseem M, Rustam N, Qamar ul Islam. Intraocular pressure after phacoemulsification using hydroxypropyl methylcellulose and sodium hyaluronate as viscoelastics. J Ayub Med Coll Abbottabad. 2007;19(1):42-5.

35. Lozano JS, Chay EY, Healey J, Sullenberger R, Klarlund JK. Activation of the epidermal growth factor receptor by hydrogels in artificial tears. Exp Eye Res. 2008;86(3):500-5.

36. Srividya B, Cardoza RM, Amin PD. Sustained ophthalmic delivery of ofloxacin from a pH triggered in situ gelling system. J Control Release. 2001;73(2-3):205-11.

37. Liu Z, Li J, Nie S, Liu H, Ding P, Pan W. Study of an alginate/HPMC-based in situ gelling ophthalmic delivery system for gatifloxacin. Int J Pharm. 2006;315(1-2):12-7.

38. Al-Kassas RS, El-Khatib MM. Ophthalmic controlled release in situ gelling systems for ciprofloxacin based on polymeric carriers. Drug Deliv. 2009;16(3):145-52. 